\title{
ФОРМУВАННЯ У СТУДЕНТІВ МЕДИЧНОГО КОЛЕДЖУ ЦІННІСНОГО СТАВЛЕННЯ ДО ВЛАСНОГО ЗДОРОВ'Я ЯК ОСНОВНА СКЛАДОВА ПІДГОТОВКИ ДО САНІТАРНО-ГІГІЄНІЧНОГО ВИХОВАННЯ ТА ПРОВЕДЕННЯ ПРОФІЛАКТИЧНОЇ РОБОТИ В СВОЇЙ МАЙБУТНІЙ ПРОФЕСІЙНІЙ ДІЯЛЬНОСТІ
}

\author{
Н. О. Пономаренко
}

\section{Полтавський базовий медичний коледж}

У статті розглянуто проблеми збереження та формування ціннісного ставлення до власного здоров'я у студентів медичного коледжу як основної складової підготовки до санітарно-гігієнічного виховання та проведення профілактичної роботи в своїй майбутній професійній діяльності.

\section{FORMATION OF VALUE ATTITUDE IN STUDENTS OF MEDICAL COLLEGE TO THEIR OWN HEALTH AS A FUNDAMENTAL PART OF PREPARATIONS TO THE SANITARY EDUCATION AND PREVENTIVE WORK N THEIR FUTURE CAREERS}

\section{N. O. Ponomarenko}

\section{Poltava Basic Medical College}

The article deals with the problem of maintaining and formation of value attitude to the health in students of medical college as the main component of preparation for hygienic upbringing and conducting preventive work in their future careers.

Вступ. Стан здоров'я населення - найважливіший показник благополуччя нації, що відображає ії соціально-економічне, екологічне, демографічне і санітарно-гігієнічне становище, $є$ одним із соціальних індикаторів економічного зростання та безпеки держави і має займати провідне місце у системі цінностей будь-якої цивілізованої країни.

Основна частина. Здоров'я та якість життя окремих людей і популяції у цілому визначається складним набором взаємопов'язаних факторів. 3 огляду на цю складність, заходи щодо зміцнення охорони здоров'я і благополуччя населення не можуть обмежуватися тільки сектором охорони здоров'я. Розробка і здійснення державних політичних заходів, спрямованих на підвищення якості життя, вимагають активної участі та залучення інших секторів суспільства на всіх етапах цього процесу [8].

У даний час значної актуальності набуває виховання відповідальності особистості за своє здоров'я, формування переконання, що від самої людини залежить багато що, у тому числі і її власне здоров'я.

(c) Н. О. Пономаренко, 2017
За останні роки інтерес учених - філософів, культурологів, соціологів, психологів, педагогів та медиків - до проблем здоров'я людини значно зростає. Вивчення проблеми здоров'я на методологічному, теоретичному й практичному рівнях взагалі й формування культури здоров'я зокрема висвітлені у вітчизняних і зарубіжних працях: М. Амосова, Г. Апанасенка, В. Бабаліч, І. Беха, В. Горащука, О. Єжової, Ю. Лісіцина, А. Маслоу та ін.

На думку В. П. Горащука, «культура здоров'я - це важливий складовий компонент загальної культури людини, зумовлений матеріальним і духовним середовищем життєдіяльності суспільства, що виражається в системі цінностей, знань, потреб, умінь і навичок 3 формування, збереження й зміцнення ії здоров'я» [3].

Під ціннісним ставленням до здоров'я розуміємо системне й динамічне психічне утворення особистості на основі емоційно-ціннісної сфери, сукупності знань про здоров'я, що обов'язково відображається та реалізується у свідомо обраному способі життя [4].

Мета роботи: обґрунтувати необхідність формування ціннісного ставлення до здоров'я в умовах медичної освіти. 
Потреби суспільства і держави в здоровій нації та трудових ресурсах країни вимагають вирішення проблем здоров'я з самого народження дитини. Не залишається осторонь цих проблем і освіта, яка виконує суспільні функції навчання й виховання. У зв'язку з сучасним станом здоров'я молодого покоління все частіше говорять про таку функцію освіти, як здоров'язбережувальна. Реалізація здоров'язбережувальної функції освіти має відбуватися шляхом формування ціннісного ставлення особистості до власного здоров'я та здоров'я оточуючих. Тому цілком правомірно говорити не стільки про здоров'язбережувальну, скільки про здоров'яформувальну функції освіти [4].

Значимість формування у студентів медичного коледжу перш за все відповідального ставлення до свого здоров'я зумовлена важливістю санітарно-гігієнічного виховання, з метою формування у них потреби вести якісну профілактичну роботу, оскільки виникнення стану «нездоров'я» в зрілому віці $\epsilon$, як правило, результатом невирішених проблем розвитку на даному етапі. Таким чином, ми готуємо майбутнього медичного працівника з абсолютно новим і принциповим ставленням до своєї професійної діяльності [7].

Аналіз освітньо-кваліфікаційної характеристики медичної сестри виявив, що крім умінь та навичок суто з догляду та спостереження за хворими, надання невідкладної долікарської допомоги, які вимагались раніше, у новій освітньо-кваліфікаційній характеристиці вперше сформульовані вміння з пропаганди санітарно-гігієнічних знань та профілактики захворювань, формування здорового способу життя у населення, навчання та виховання свідомого ставлення до здоров'я [5], як це прийнято в інших країнах світу.

Зазначено, що у підготовці медичних сестер та фельдшерів ще існують певні проблеми, які визначаються відсутністю єдиної системи фахової підготовки студентів до реалізації знань про здоровий спосіб життя у майбутній професійній діяльності. Сьогодні підготовка студентіву даному напрямкузабезпечується переважно традиційними методами без урахування новітніх процесів і технологій. Класична професійна медична освіта необґрунтовано мало відводить часу на передачу знань студентам щодо індивідуального здоров'я людини, значення здорового способу життя, збереження, зміцнення та розвиток здоров'я.

На жаль, традиційна система первинної медикосоціальної допомоги залишається орієнтованою переважно на хворобу. Вона не передбачає конкретних активних заходів первинної профілактики, надання послуг, спрямованих на збереження та зміцнення здоров'я, формування корисних навичок. Співвідношення обсягу профілактичної роботи медичної сестри до лікування сягає 1:10 [6].

У вищих медичних навчальних закладах при підготовці медичних сестер та фельдшерів основний обсяг навчальних годин відводиться на вивчення клінічних дисциплін і лише незначна кількість годин на питання профілактики та збереження здоров'я.

Головним завданням медичного навчального закладу на сучасному етапі $є$ підготовка фахівців, здатних нестандартно, гнучко та вчасно реагувати на зміни, які відбуваються в світі. Тому для підготовки студентів до професійної діяльності доцільно використовувати інноваційні методи навчання та виховання 3 метою формування ціннісного ставлення до здоров'я.

Варто зазначити, що проблема здорового способу життя лежить в основі формування особистості. У ході роботи виникає низка питань, передусім пов'язаних із недосконалістю роботи в даному напрямку (зокрема недосконалістю профілактичних і оздоровчих технологій, їхньою низькою ефективністю, відсутністюуваги до проблем якості життя при розробці профілактичних програм, ігноруванням інтересів окремої людини при проведенні масових оздоровчих і профілактичних компаній, непопулярністю медичної і соціальної профілактики серед молоді) [1].

У наш час особливого значення набуває формування здорового способу життя молоді, зокрема студентів медичних навчальних закладів I-II рівнів акредитації. Від того, наскільки успішно зможуть сформуватися та закріпитися у свідомості навички здорового способу життя в молодому віці, залежатиме в майбутньому реальний спосіб життя та професійна діяльність, яка може перешкоджати або навпаки сприяти розкриттю потенціалу особистості. Молодь найбільш сприйнятлива до різноманітних формуючих і навчальних впливів, тому існує необхідність раннього формування потреби збереження особистого здоров'я та проведення профілактичної роботи серед населення з метою формування здорової нації. Робота в даному напрямку дозволяє нейтралізувати в майбутньому розвиток факторів ризику різноманітних захворювань, запобігти виникненню шкідливих звичок. Адже саме молодь $є$ найперспективнішою віковою категорією щодо формування здорового способу життя [2].

Ціннісне ставлення до власного здоров'я передбачає сформованість особистості та вміння цінувати себе як носія фізичних, духовних та соціальних сил. Воно $є$ важливою умовою формування у студентської молоді активної життєвої позиції. 
Ціннісне ставлення до свого фізичного «Я» - це вміння особистості оцінювати свою зовнішність, тілобудову, поставу, розвиток рухових здібностей, фізичну витривалість, високу працездатність, функціональну спроможність, здатність відновлювати силу після фізичного навантаження, вольові риси, статеву належність, гігієнічні навички, корисні звички, стан свого здоров'я та турбуватися про безпеку власної життєдіяльності, здоровий спосіб життя та активний відпочинок.

Ціннісне ставлення до свого психічного «я» передбачає вихованість культури пізнання власного внутрішнього світу - думок, переживань, станів, намірів, прагнень, цілей, життєвих перспектив, ідеалів, цінностей, ставлень. Важливо навчити зростаючу особистість сприймати себе такою, якою вона $є$, знати свої позитивні та негативні якості, сприяти формуванню неї реалістичної Я-концепції, готовності та здатності до самовдосконалення, конструктивної самокритичності.

Ціннісне ставлення до свого соціального «я» виявляється у таких ознаках: здатності орієнтуватися та пристосовуватися до нових умов життя, конструктивно на них впливати; визначенні свого статусу в соціальній групі, налагодженні спільної праці з дорослими та однолітками; вмінні запобігати конфліктам, справедливому і шляхетному ставленні до інших людей.

Висновки. Незважаючи на єдині загальнодержавні навчальні програми для медичних навчальних закладів I-ІІ рівнів акредитації потрібно розробити відповідну програму підготовки студентів середньої ланки щодо пропаганди здорового способу життя та формування ціннісного ставлення до здоров'я, врахо-

\section{СПИСОК ЛІТЕРАТУРИ}

1. Бабаліч В. А. Формування у студентів медичного коледжу готовності до пропаганди і реалізації ідей здорового способу життя у майбутній професійній діяльності : дис. ... канд. пед. наук : 13.00.04 / Вікторія Анатоліївна Бабаліч. - Кіровоград, 2007. - 258 с.

2. Горай О. В. Особливості санітарно-гігієнічного виховання та профілактичної роботи серед підлітків / О. В. Горай // Наукові праці. Серія: Педагогіка, психологія і соціологія. - Донецьк : ДВНЗ «ДонНТУ», 2009. - № 5 (155). Частина 1. - С. 345-350.

3. Горащук В. П. Концептуальні основи формування культури здоров'я школяра / В. П. Горащук // Нові технології навчання. - К. : НМЦВО, 2000. - № 28. - С. 206-213.

4. Єжова О. О. Організаційно-педагогічні умови формування ціннісного ставлення до здоров'я в професійнотехнічних навчальних закладах / О. О. Єжова // Педагог професійної школи. - 2009. - № 1. - С. 186-195.

5. Довідник кваліфікаційних характеристик професій працівників системи охорони здоров'я. - Вип. 78. - С. 31-34. вуючи вік, життєвий досвід і громадську зрілість студентів. Така організація роботи вимагає від викладачів диференційного підходу при постановці виховних завдань та під час вибору форм і методів навчання.

Пошук нових нестандартних форм навчання і формування особистості щодо здорового способу життя потребує зміни аспектів наукових досліджень у напрямку вивчення власне людських проблем. Потрібно сформувати у підростаючого покоління потребу до ведення здорового способу життя та установку на тривале здорове життя. Необхідно показати значення самої людини, ії свідомості й мислення для збереження та відновлення здоров'я. У зв'язку з цим основним механізмом практичної готовності до пропаганди і реалізації ідей здорового способу життя студентами-медиками у майбутній професійній діяльності стає процес цілеспрямованого докладання зусиль для покращення здоров'я і благополуччя населення. Він включає розробку ефективного проекту на користь здоров'я населення; впровадження програм із надання людям освітньо-інформаційних послуг; ознайомлення з методами і прийомами ефективної діяльності на користь власного здоров'я.

У результаті аналізу сутності поняття «формування ціннісного ставлення до здоров'я» ми вважаємо, що це поняття вчені розглядають комплексно із врахуванням фізичного, психічного і соціального аспектів. Ми підтримуємо думку, що здоровий спосіб життя потрібно розглядати як своєрідну формулу здоров'я, що означає усі дії людини, які безпосередньо спрямовуються або опосередковано торкаються формування, збереження, зміцнення, споживання, відновлення і передачі здоров'я.

6. Назаренко Л. І. Формування готовності майбутніх медичних сестер до проведення профілактичної роботи / Л. І. Назаренко // Збірник матеріалів Всеукраїнської науково-методичної інтернет-конференції (Черкаси, 15 жовтня 2014 р.). - Черкаси, 2014. - С. 90-95.

7. Пономаренко Н. О. Профілактична спрямованість як основна складова професійної діяльності медичного працівника середньої ланки / Н. О. Пономаренко // Медсестринство. - 2016. - № 4. - С. 53-54.

8. Щорічна доповідь про стан здоров'я дорослого населення, санітарно-епідемічну ситуацію та результати діяльності системи охорони здоров'я України. 2015 рік [Електронний ресурс] : доповідь Українського інституту стратегічних досліджень. - Режим доступу : http:// www.uiph.kiev.ua/dawnload/Vidavnictvo/Shchorichna\%20 dopovid/Щорічна\%20доповідь.2016.pdf

Отримано 02.03.17 